\title{
James R. Otteson, Adam Smith, London: Bloomsbury, 2013, 200 pp.
}

DOI: http://dx.doi.org/10.12775/RF.2015.017

Adam Smith is a thinker whose work has been widely discussed and analysed for centuries now. It is remarkable that in the $21^{\text {st }}$ century we see no significant decline in the number of studies on his philosophy. During recent years some noteworthy books have been published on this subject, including The Cambridge Companion to Adam Smith that gives an overall picture of Smith's theory. Unfortunately, in Poland little attention has been paid to Smith's philosophy. The most reliable source on the spectrum of Smith's thought remains Stefan Zabieglik's book, published in 2003, entitled simply, Adam Smith.

James R. Otteson's book which I would like to focus on, with a similarly simple title, has been written in an accessible form for someone who neither specialises in Smith's thought nor in the philosophy of the Scottish Enlightenment. At the same time, it is not a simplistic presentation of Smith's philosophy - it also carries interesting interpretations and a significant amount of opinion from the author on Smith's thought, its coherence and validity.

Otteson's Adam Smith was first published in 2011 and its paperback edition was published in 2013, both as a part of the Major Conservative and Libertarian Thinkers series. In my opinion, Adam Smith can be perceived as neither a conservative nor a libertarian thinker ${ }^{1}$. His economic theory is rather liberal - he mentions the role of local knowledge, focuses on spontaneous processes on the market that are outcomes of people's individual choices, and underlines the role of the division of labour.

1 Lauren Brubaker in his text Why Adam Smith is neither a conservative nor a libertarian (published in "Adam Smith Review” vol. 2, p. 197-202, which is a review of Otteson's first book on Adam Smith: Adam Smith's Marketplace of Life, Cambridge University Press, Cambridge 2002) stated: "Smith is primarily a liberal, although his recognition of the dangers of the "spirit of system « makes him a moderate liberal. Thus, while explicitly sympathetic to context and political realities, he cannot be a conservative traditionalist. Ironically for Otteson's argument, he is too aware of the dangerous appeal of simple systems to ever be a doctrinaire libertarian". 
Simultaneously, he gives an important role to government regulations which goes far beyond the idea of a night-watchman state: not only creating the police, courts and army, but also, amongst other things, mentioning free education for children, preventing monopolies, working on banking regulations and caring for the majesty of the ruler. Smith's moral theory assigns an important role to tradition and existing norms though it rather focuses on a slow modification of the rules and on the fact that we learn morality through society. Thanks to the guidance of others, we learn how to use sympathy and imagination in the process of giving moral judgements..

In the book's epilogue, Otteson himself tries to justify the book's place in the abovementioned series: "It is hard to classify Adam Smith politically, since he seems to embody elements of today's notion of »liberal« and »conservative «, as well as »libertarian «/.../ He believed history demonstrated the necessity of a government defending private property and interfering only little in people's economic affairs. Yet he was pragmatic about his principles: they were defaults that could, in exigencies, be violated. He was this no principled purist, which probably disqualifies him as a libertarian /.../ Smith's concern for the poor leads some commentators to suggest that he must have been a proto"progressive " liberal" 2 . At some point the author states that, "I would instead call Smith a classical liberal". The failure to justify the fact that the book belongs in the series, however, does not influence the content of the book itself. It can be rather regarded as a minor error of the publisher.

The book addresses multiple issues concerning Smith's philosophy. It starts with the philosopher's brief biography and a short summary of his two main works: The Theory of Moral Sentiments and An Inquiry to the Nature and Causes of the Wealth of Nations. Apart from those two books, Otteson also analyses Smith's Considerations Concerning the First Formation of Languages and mentions some of his other minor works.

He considers Smith's approach to language and its changes to be a manifestation of a spontaneous processes like those understood in the theories of unintended order. He noticed that, though people are unable to control global processes, they might notice little changes when a language - which is a device created by humans - develops as an answer to people's needs ${ }^{3}$. I find such an approach to Smith's theory of language very convincing, although I, myself, would put more emphasis on individual actions. However, such a view shows that Otteson notices an important liaison between various aspects of Smith's philosophy. He is not

2 J.R. Otteson, Adam Smith, Bloomsbury, Nowy Jork, London 2013, p. 164-165.

3 J.R. Otteson, Adam Smith, op.cit., p. 16-21. 
alone in noticing this. When we learn a language, we do that through observation and imitation - the same thing also happens within morality ${ }^{4}$.

James R. Otteson refers to the spontaneous order concerning numerous aspects of Adam Smith's thought. When discussing Smith's political economy, he also focuses on the idea of spontaneous order and, as he calls it, Great Mind Fallacy. With this notion he understands "/.../the belief, or hope, that there is someone out there smart enough and benevolent enough to make these decisions [mostly economic and political decisions - A.M.] for us, leaving us peacefully secure in the knowledge that somebody somewhere is protecting and taking care of us" ${ }^{\prime \prime}$. He regards the Great Mind Fallacy argument as coming from three other arguments: "the Local Knowledge Argument, the Economizer Argument, and the Invisible Hand Argument" ${ }^{\prime \prime}$. Though crafty, his argument presenting the Great Mind Fallacy and its consequences is quite unclear.

After analysing the "Genealogy of Morality" (Otteson's words he presents his interpretation of Smith's moral philosophy) the author of Adam Smith devotes his attention to the issue of human nature. Smith himself was not convinced that it would be possible to present a full description of human nature ${ }^{7}$ and put emphasis on the fact that we are born as similar human beings and the way we were raised and acquired our experiences have a significant influence on us. He also seemed to be describing certain features and numerous motivations of human beings as well as the role of the society ${ }^{8}$. Focusing on the issue of the market, in Adam Smith James R. Otteson mentions three important features describing the human disposition to truck and barter, the will to better one's own condition ${ }^{9}$ and be self-interested ${ }^{10}$ (it should be noted that in his books Otteson presents a very interesting explanation of why

${ }^{4}$ C.J. Swearingen, Adam Smith on Language and Rhetoric: the ethics of Style, Character and Propriety [in:] C.J. Berry, M.P. Paganelli, C. Smith (red.), The Oxford Handbook of Adam Smith, Oxford University Press, Oxford 2013, p. 167.

5 J.R. Otteson, Adam Smith, op.cit., p. 101.

6 J.R. Otteson, Adam Smith, op.cit., p. 97.

7 P.B. Mehta, Self-Interest and Other Interests [in:] K. Haakonssen (ed.), The Cambridge Companion to Adam Smith, op. cit., p. 247-248.

8 A. Smith, An Inquiry into the Nature and Causes of Wealth of Nations, R. H. Campbell, A. S. Skinner (ed.), Liberty Fund, Indianapolis 1981, vol. I, p. 26-27; A. Salomon, Adam Smith as Sociologist, „Social Research”, vol.12, nr 1 (luty 1945), p. 27-28.

9 Weinstein criticized Otteson on that matter, considering the will to better one's own condition as synonymous to the will to become a better person (J.R. Weinstein, Adam Smith's Pluralism. Rationality, Education and the Moral Sentiments, Yale University Press, New Haven, Londyn 2013, p. 53,56). I would rather agree with Otteson that the will to live a good, prosperous life is considered by Adam Smith as one of people's most important motivations.

${ }_{10}$ J.R. Otteson, Adam Smith, op.cit., p. 93-97. 
we address peoples' self-interest in a market exchange situation ${ }^{11}$ ). In the Marketplace of Life, Otteson listed many such features, giving a more elaborate description of human being, as was seen by Adam Smith. That description includes sympathy, self-partiality, sociability, being self-interested, a desire to be praiseworthy, the impulse to adopt the perspective of an impartial spectator and having a drive for self-preservation and security ${ }^{12}$. Otteson's Adam Smith would rather benefit from making this list even more extensive and with more elaborate description.

Further on the author presents his solution to the Adam Smith Problem. In this case it would be hard to discuss James R. Otteson's Adam Smith without mentioning his previous book on the Scottish philosopher's thought, entitled Adam Smith's Marketplace of Life. Adam Smith is clearly based on the ideas introduced in the Marketplace of Life. The "Marketplace Model"13, as the author calls it, can be found in both books. It shows an analogy between creating general rules of morality ${ }^{14}$ and the way markets work. He presented a vision of a local market where people exchange goods. His Market Model is supposed to be describing the way in which, in the area of economy, order emerges on the market and freedom makes it easier to create a relationship based on exchange. Even if there are no strong regulations, order will remain, since they do not only follow the law, they emerge in a spontaneous way. The same, according to Otteson, goes with morality and language. However, his view was criticized ${ }^{15}$. Unfortunately, he put too much stress on the market and he tried to make other analyzed areas match the criteria of eco-

11 First of all, it needs to be underlined that one cannot regard Smith's theory in terms of considering people to be always egoistic or to think of his books as presenting opposing views of human nature (The Theory of Moral Sentiments - altruism, the Wealth of Nations - egoism). Such an interpretation, being a part of the early stage of discussion on the Adam Smith Problem, is not valid and is rather a myth. I will not explain at this point in detail why such a view is a mistake. However, it is a fact that Smith, amongst other human motivations, underlined the role of self-interest. He found it natural that during market transactions people search to address others' self-interest rather than benevolence. Otteson's interpretation of that fact is very interesting. he showed that it is a relation we rarely have with our friends or loved-ones. We exchange goods on the market with strangers. It is a routine and we do it fast. So it is easier, quicker and more efficient to try to search to fulfil others' needs to have our needs fulfilled (J.R. Otteson, Adam Smith, op.cit., p. 95-96.).

12 J.R. Otteson, Adam Smith's Marketplace of Life, op.cit., p. 84-90.

13 J.R. Otteson, Adam Smith, op.cit., p. 126-129.

14 More about the general rules of morality can be found in e.g.: Ch.L. Griswold, Adam Smith and the Virtues of Enlightenment, op. cit., p. 185-186; A. Smith, The Theory of Moral Sentiments, D. D. Raphael, A. L. Macfie (ed.), Liberty Fund, Indianapolis 1982, p. 160; G.R. Morrow, Adam Smith: Moralist and Philosopher, "The Journal of Political Economy", Vol. 35, no 3 (June 1927), p. 339.

15 e.g.: J.R. Weinstein, Adam Smith's Pluralism. Rationality, Education and the Moral Sentiments, op. cit. 
nomic exchange instead of "softening" the model and looking for more real similarities.

Though the model itself can be found to be insufficient and with some disadvantages, one can admire Otteson's courage to present such an interpretation that pays attention to the spontaneous processes which underlie Smith's thought. Especially that it includes more than just the two most widely discussed of Smith's books (The Theory of Moral Sentiments and the Wealth of Nations) as he also highlights the existence of similar processes in Smith's Considerations Concerning the First Formation of Languages.

James R. Otteson concludes the book with two short chapters presenting his view on what he believes Smith's mistakes were and what he got right (he mentions here the idea of spontaneous order, theory of sympathy, Smith's view on human nature and his remarks on markets and prosperity).

To sum up, Otteson's Adam Smith offers an interesting interpretation of Adam Smith's philosophy that can be inspiring both for someone at the beginning of their adventure with the thought of the author of the Theory of Moral Sentiments, as well as for someone who is deeply familiar with the subject. Some of the Otteson's ideas are fresh. I must admit that I agree with many of Otteson's remarks and find his analyses to be thorough and consistent. Otteson's book is quite an interesting introduction to a deeper analysis of Smith's thought. It presents a strong interpretation so, it would be worthwhile to have become acquainted with Adam Smith's works before reading it. Nevertheless, the variety of issues addressed in the book (though it is much less detailed and less objective than e.g.: The Cambridge Companion to Adam Smith ${ }^{16}$ ) and the way it was written make it one of the most interesting positions written within the last few years.

Anna Markwart

16 K. Haakonssen (ed.), The Cambridge Companion to Adam Smith, Cambridge University Press, Nowy Jork 2006. 